\title{
Europeanizing the State Constitution-- The Water and Power Amendment
}

$\mathrm{G}$ OVERNMENTAL opposition to power outside of the government has created various commissions. To accomplish their purpose they have to receive greater power than the power which they oppose. Likewise, to protect the public from being itself dominated by the commissions, maintenance of the common constitutional checks in the public interest becomes the more important. Without that, the commissions would become a mere replacement of the abuses which they overcome in others. The proposal sometimes found to discard the constitutional safeguards against this is shortsighted in the extreme.

An instance, of wider extent than its name suggests, is the constitutional amendment called the Water and Power Bill, defeated at the last election and on the ballot again unchanged. Its scope is much wider than its name.

1. The provisions of the Water and Power Bill are mainly as follows: By constitutional amendment it puts in the hands of a board of five men "the waters and lands of the State" (sec. 3, sub. d). Also such waters and lands as they can get from the United States and from neighboring States (sec. 3, sub. f, g). Also they may get lands, waters "and any other property" by buying "or other legal means." What to build and what to operate is also left to their discretion (sec. 3, sub. a) ; - a very comprehensive discretion to do "any and all things" concerning water or electricity, and to get or make "any property or thing" that they consider "convenient" (sec. 3, sub. a and b). For this the Bill by section 5 puts in their hands $\$ 500,000,000$ in State bonds. ${ }^{1}$

It would thus create in five men by constitutional provision an unlimited personal discretion with nothing specified.

2. Among the elements of popular government is the right of the people to make their own laws. The Bill grants to the Board power to "adopt rules and regulations" (sec. 3 , sub. k), and these will have the force of legislation over the agriculture, manufacturing, lighting and

1 A finance committee is named to do the clerical work, subject to supreme control of the bonds by the board. 
communications of the State. In other sections the five men become their own rate-fixing authority for water delivered to the consumers out of the $\$ 500,000,000$ or for electricity furnished (sec. 8). If enough money is not raised from consumers to meet the bonds, "there is hereby appropriated from the general fund in the State Treasury such sum annually as will be necessary" (sec. 9). What the five men do not raise from the people as ratepayers, they may take from the people as taxpayers.

The five members of the Board may, and obviously will, thus legislate over the people of the State. The people through their representatives are foreclosed from passing laws to avoid the Board's arbitrary refusal of service to citizens, favoritism in its service to localities, kinds of industries, factories, crops, towns, and other like legislation on which public welfare will depend. The people through their representatives in the legislature may have some idea what the rules ought to be in other respects also. But the effect of the Bill will be to release the five men from such constitutional considerations.

Being themselves chartered by the Constitution, they are to be supreme in their field, to follow their personal ideas and legislate as they please; and the legislature is closed.

3. Donation of supreme power similarly closes the courts.

Under the Bill the five men will hear and be their own judges of complaints that may arise, including complaints against themselves. Being placed in the Constitution, they are as high as the courts. Even the Supreme Court, which was left superior to the Railroad Commission, is not granted any authority by the Bill to hear complaints against the water and power Board.

The ordinary man is so used to knowing that if he feels himself wronged by public officials he can turn at present to the courts for as impartial a hearing as human nature permits, that it is hard to realize that the Bill contemplates a situation with the courts gone. It can be brought to mind somewhat by the following, not overdrawn, description.

"The benefits of the integrity and moderation of the judiciary have already been felt in more States than one; and though they may have displeased those whose sinister expectations they may have disappointed, they must have commanded the esteem and applause of all the virtuous and disinterested. Considerate men, of every description, ought to prize whatever will tend to beget or fortify that temper in the courts; as no man can be 
sure that he may not be tomorrow the victim of a spirit of injustice by which he may be a gainer today. And every man must now feel that the inevitable tendency of such a spirit is to sap the foundations of public and private confidence, and to introduce in its stead universal distrust and distress."

It might be thought that the Bill would endeavor to insure to consumers a fair hearing by the Board, in view of the loss of access to impartial courts. But the Board is as unrestricted in the method of reaching its decision as in other matters. No notice to consumers is guaranteed by the Act, no hearing, no taking of evidence before a decision.

Doubtless the arrangement would meet its deserved overthrow at the hands of the Federal Constitution. In discussing an order of a state public service commission, the Supreme Court of the United States spoke of "such a want of hearing or such arbitrary or capricious action on the part of the commission as to violate the due process clause of the constitution." 3 Of an act of the immigration officials in the exclusion of foreigners it was said that there must be a "fair investigation" by the executive officers and "the decision must be after a hearing in good faith, however summary," at which evidence is taken and made of record, open and not secret. ${ }^{4}$ The Interstate Commerce Commission Act and the Federal Trade Commission Act provide in the statute for an administrative hearing, wherefore expressions under those acts that the need is constitutional may be obiter; they are, however, strong: "A finding without evidence is arbitrary and baseless" and "it has been distinctly recognized that administrative orders, quasi judicial in character, are void if a hearing was denied." "To refuse to consider evidence introduced or to make an essential finding without supporting evidence is arbitrary action."' "All parties must be fully apprised of the evidence submitted or to be considered and must be given opportunity to cross-examine witnesses, to inspect

2 The Federalist, No. 78.

${ }^{8}$ New York, etc. Co. v. McCall (1920) 245 U. S. 345, 348-349, 62 L. Ed. 337, 38 Sup. Ct. Rep. 122.

${ }^{4}$ Kwock Jan Fat y. White (1920) 253 U. S. 454, 457, 64 L. Ed. 1010, 40 Sup. Ct. Rep. 566, 570. Likewise, Carstens v. Pillsbury (1916) 172 Cal. 572, 158 Pac. 218; Roanoke W. Com. v. Commonwealth (1923) 119 S. E. 268 (Va.).

5 I. C. C. v. Louisville R. Co. (1913) 227 U. S. 88, 91, 57 L. Ed. 431, 33 Sup. Ct. Rep. 185, 186-187.

${ }^{6}$ Baltimore \& Ohio R. Co. v. U. S. (1924) 68 L. Ed. -, 44 Sup. Ct. Rep. 317. 
documents, and to offer evidence in explanation or rebuttal." ${ }^{\text {. An }}$ admimistrative decision without support in the evidence as recorded is void. ${ }^{8}$

The notice and hearing and sufficient evidence,-the fundamentals of civilized justice,-must, moreover, be provided by law to satisfy the Federal Constitution. They can not be left to the discretion of the Board to give or withhold.

"Nor can extra-official or casual notice, or a hearing granted as a matter of favor or discretion, be deemed a substantial substitute for the due process of law that the Constitution requires. .... 'It is not enough that the owners may by chance have notice, or that they may as a matter of favor have a hearing. The law must require notice to them and give them the right to a hearing and an opportunity to be heard.' The soundness of this doctrine has repeatedly been recognized by this court."

The Federal Constitution may condemn also the Bill's enactment of finality for the Board's rulings in the face of other forms of abuse. Enactment of administrative finality upon consumers in the face of abuse of discretion is condemned in a well-known early case.

"When we consider the nature and the theory of our institutions of government, the principles upon which they are supposed to rest; and review the history of their development, we are constrained to conclude that they do not leave room for the play and action of purely personal and arbitrary power. .... The very idea that one may be compelled to hold his life, or the means of living, or any material right essential to the enjoyment of life, at the will of another, seems to be intolerable in any country where freedom prevails, as being the essence of Slavery itself." ${ }^{\prime \prime 10}$

7 I. C. C. v. Baltimore, etc. Co. (1912) 226 U. S. 14, 57 L. Ed. 104, 33 Sup. Ct. Rep. 5.

8 Federal Trade Commission v. Curtis Pub. Co. (1923) 260 U. S. 568, 67 L. Ed. 408, 43 Sup. Ct. Rep. 210; I. C. C. v. Louisville R. Co., supra, n. 5 ; Baltimore \& Ohio R. Co. v. U. S., supra, n. 6 . "..... although findings of fact made by the board or commission are generally binding, they may yet be reviewed as matter of law where absolutely unsupported by the evidence." Great Western Co. v. Pillsbury (1915) $170 \mathrm{Cal}$. 180, 187, 149 Pac. 35, citing:Rakiec v. Deleware etc. Co. (1913) 88 Atl. 953 (N. J.); M'Coffrey v. G. N. Ry. Co. (1901) 36 Ir. L. T. Rep. 27; Fenton v. Throley \& Co. [1903] App. Cas. 443; Sexton v. Newark Dist. Tel. Co. (1913) 84 N. J. L. 85, 86 Atl. 450; Bryant v. Fissell (1913) 84 N. J. I. 72, 86 Atl. 458; Rayner v. Sligh Furn. Cn. (1914) 180 Mich. 168, 146 N. W. 665; Reck v. Whittlesbirger (1914) 181 Mich. 463, 148 N. W. 247, Ann. Cas. 1916C 771; Pigeon v. Emp. Liab. Ass. Corp. (1913) 216 Mass. 51, 102 N. E. 933; In re Herrick (1914) 217 Mass. 111, 104 N. E. 432 .

${ }^{9}$ Coe v. Armour Fertilizer Works (1915) 237 U. S. 413, 424, 59 L. Ed. 1027, 35 Sup. Ct. Rep. 625, 629.

10 Yick Wo v. Hopkins (1886) 118 U. S. 356, 359, 30 L. Ed. 220, 6 Sup. Ct. 
While there have been distinctions how far administrative action by rule is different from action without rule, in its effect upon the question of abuse, ${ }^{11}$ yet it has been often reaffirmed that if the abuse exists the administrative officials at that point cease to be officers of the state, and become individual trespassers. ${ }^{12}$ This is alternatively expressed in the irrigation cases ruling that vested rights are protected, or that administrative action is not final against those whose rights it would take away. ${ }^{13}$ So far as the Supreme

Rep. 1064. See also In re Dart (1916) 172 Cal. 47, 155 Pac. 63, Ann. Cas. 1917D 1127, I. R. A. 1916D 905; North Powder Co.v. Pac. Fruit Com. (1921) 101 Ore. 18, 198 Pac. 893, 896; Tarpey v. McClure (1923) 190 Cal. 593, 213 Pac. 983; Ex Parte Quong (1911) 161 Cal. 220, 118 Pac. 740; Hewitt v. Board of Medical Examiners (1906) 148 Cal. 590, 84 Pac. 39, 113 Am. St. Rep. 315, 3 L. R. A. (N. S.) 896, 7 Ann. Cas. 750; Schaezlein v. Cabaniss (1902) 135 Cal. 466,67 Pac. 755, 87 Am. St. Rep. 122, 56 L. R. A. 733; Dougherty v. Austin (1892) 94 Cal. 601, 28 Pac. 834, 29 Pac. 1092, 16 L. R. A. 161 ; Slinger v. Henneman (1875) 38 Wis. 504; State ex rel. Adams v. Burdge (1897) 95 Wis. 390, 70 N. W. 347, 60 Am. St. Rep. 123, 37 L. R. A. 157; Mitchell v. State (1901) 134 Ala. 392, 32 So. 687; Boyd v. Board of Council of Frankfort (1903) $117 \mathrm{Ky}$. 199, 77 S. W. 669, 111 Am. St. Rep. 240; State v. Kuntz (1894) 47 La. Ann. 106, 16 So. 651; State v. Field (1853) 17 Mo. 529 , 59 Am. Dec. 275 ; Mayor etc. of Newbern v. McCann (1900) 105 Tenn. 159, 58 S. W. 114, 50 L. R. A. 476; See also, Douglas v. Noble (1923) 261 U. S. 165, 67 L. Ed. 590, 43 Sup. Ct. Rep. 303,305 ; Notes in 36 Harvard Law Review, 1020; 37 Harvard Law Review, 1119.

"But whatever may be the precise powers of the Water Commissioners, deducible from this mass of confusion, we are satisfied it was not intended to confer upon them a mere arbitrary discretion in the apportionment of the water, to be exercised, it may be, in utter disregard of the rights of the proprietors. They are merely agents, selected for the public convenience, to regulate the distribution of water according to the rights of the parties in interest. But they are not above the law, and have not the power to distribute the water, according to their whim or caprice, regardless of the rights of those entitled to it; and we are therefore of opinion that their action in distributing to the defendants more than their just proportion of water, does not conclude the plaintiffs from obtaining redress in the courts." Daley v. Cox (1874) 48 Cal. 127, 130-131. $283,288$.

11 See Mahler v. Eby (1924) 264 U. S. 32, 68 L. Ed. -, 44 Sup. Ct. Rep. 12 Truax v. Raich (1915) 239 U. S. 33, 60 L. Ed. 131, 36 Sup. Ct. Rep. 7, 9; Pub. Serv. Com. etc. v. Corboy (1919) 250 U. S. 153, 63 L. Ed. 905, 39 Sup. Ct. Rep. 440,441 ; U. S. v. Henrylyn Co. (1912) 205 Fed. 970 ; and cases in note 10 , supra.

13 Youngs v. Regan (1911) 20 Idaho, 275, 118 Pac. 499; King v. Chamberlin (1911) 20 Idaho, 504, 118 Pac. 1099; Gard v. Thompson (1912) 21 Idaho, 485, 123 Pac. 497; Marshall v. Niagara Co. (1912) 22 Idaho, 144, 125 Pac. 208; Washington Sugar Co. v. Goodrich (1915) 27 Idaho, 26, 147 Pac. 1073; Sarrett v. Hunter (1919) 32 Idaho, 536, 185 Pac. 1072, 1074; Sanderson v. Salmon River Co. (1921) 34 Idaho, 303, 199 Pac. 999; Clark v. Hansen (1923) 35 Idaho, 449, 206 Pac. 808, 810; Gearhart v. Frenchman etc. Irr. Dist. (1915) 97 Neb. 764, 151 N. W. 323; Bergman v. Kearney (1917) 241 Fed. 884; Knox v. Kearney (19i4) 37 Nev. 393, 142 Pac. 526; Pitt v. Scrugham (1921) 44 Nev. 418, 195 Pac. 1101; Gay v. Hicks (1912) 33 Okla. 675, 124 Pac. 1077; Owens v. Snider (1915) 52 Okla. 772, 153 Pac. 833; Pringle Falls etc. Co. v. Patterson (1913) 65 Ore. 474, 132 Pac. 527; St. Germain Co. v. Hawthorne D. Co. (1913) 32 S. D. 260, 143 N. W. 124; Board of Water 
Court of the United States is concerned, any substantial degree (even partial) of hampering judicial recourse against abuse of power is disapproved. Where the statute provided that one who undertook to apply for judicial redress should be subject to penalties, the court declared its invalidity and has very recently reapproved that position. ${ }^{14}$ A special statutory recourse from the administrative to the courts, hampered by a provision forbidding a stay was lately overthrown. ${ }^{15}$ Against the charge of confiscation, finality may not be enacted even upon non-jurisdictional facts; upon that the judicial tribunal must be left free to make a determination "upon its own independent judgment as to both law and facts; otherwise the order is void because in conflict with the due process clause, Fourteenth Amendment." ${ }^{\prime 16}$

4. It is not very comforting to pride in self-government to assume that if we abandon the State Constitution, that of the United States will protect us by invalidating the folly. It brings prominently to realization, however, that precautions for the rights of the people against the Board itself are ignored by the Bill, and that our constitutions grew out of hard experience with personal government of such kind.

Engineers v. McKnight (1921) 111 Tex. 82, 229 S. W. 301, 305; Chandler v. Utah Copper Co. (1913) 43 Utah, 479, 135 Pac. 106; Peterson v. Eureka Co. (1918) 53 Utah, 70, 176 Pac. 729; Brady v. McGonagle (1921) 57 Utah, 424, 195 Pac. 190; Ýates et al. v. Newton et al. (1921) 59 Utah, 105, 202 Pac. 210; State v. Superior Court (1918) 102 Wash. 291, 173 Pac. 19; State ex rel. Wausau Co. v. Bancroft (1912) 148 Wis. 124,134 N. W. $330,38 \mathrm{~L}$. R. A. (N. S.) 526 ; U. S. v. Ide (1921) 277 Fed. 373, 382; Big Horn Co. v. State (1915) 23 Wyo. 271, 148 Pac. 1110; Wiel, Water Rights (3d ed.) $\S \S 410,1193$. 14 "It was in the light of the fact that the penalty was imposed for charging other than those statutory rates, whose reasonableness was a matter of doubt and uncertainty, that this court in the Young case, speaking through Mr. Justice Peckham, pointed out that a law which in terms or by the operation of deterrent penalties made statutes or orders of a commission conclusive as to the sufficiency of rates would be unconstitutional. He summed up the discussion as follows: 'It may therefore be said that when the penalties for disobedience are by fines so enormous and imprisonment so severe as to intimidate the Company and its officers from resorting to the courts to test the validity of the legislation, the result is the same as if the law, in terms, prohibited the company from seeking judicial construction of laws which deeply affect its rights." "(Italics mine.) Wadley Southern R. Co. v. Georgia (1915) 235 U. S. 651, 663, 59 L. Ed. 405, 35 Sup. Ct. Rep. 214, 218-219.

${ }_{15}$ Pacific Tel. Co. v. Kuykendall (1924) 68 L. Ed. - 44 Sup. Ct. Rep.553; Pac. Tel. \& Tel. Co.v. Cushman (1923) 292 Fed. 930, 932-933; But compare Pacific I. S. Co. v. Lewis (1915) 241 U. S. 440, 60 L. Ed. 1084, 36 Sup Ct. Rep. 637.

${ }^{16}$ Ohio Valley W. Co. v. Ben Avon Borough (1919) 253 U. S. 287, 289, 64 L. Ed. 908, 40 Sup. Ct. Rep. 527, 528; Bluefield etc. Co. v. Pub. Serv. Com. (1923) 262 U. S. 679, 67 L. Ed. 1176, 43 Sup. Ct. Rep. 675, 678; Dayton etc. 
Our constitutions came into being on breaking away from European conditions, to tell the persons who govern us what they may do, but equally strongly what they may not do. Chief among these limitations, our principle of government has been to entrust to some officials the making of our laws as legislators, to entirely different persons the interpretation of the laws as judges, and separate from both of them are the executives who put the laws into action. We have held to keeping them apart in the main, so that we may continue to have public servants and not rulers. It is universally admitted that some degree of overlap is unavoidable. ${ }^{17}$ Few deny, however, that policy demands that the overlap be kept as small as possible.

"There is no liberty if the power of judging is not separated from the legislative power and from the executive power. If it were joined to the legislative power, the power over the life and the liberty of the citizens would be arbitrary; for the judge would be legislator. If it were joined to the executive power, the judge might have the force of an oppressor."18

\section{A classical statement of this has been:-}

"In the government of this commonwealth, the legislative department shall never exercise the executive and judicial powers, or either of them: the executive shall never exercise the legislative and judicial powers, or either of them: the judicial shall never exercise the legislative and executive powers, or either of them: to the end it may be a government of laws and not of men."19

As the branch of government which interprets the laws, the courts, in saying when the overlap has been carried too far, are lenient and let a good deal go through. In a number of instances,

Co. v. U. S. (1923) 263 U. S. 456, 68 L. Ed. 216, 44 Sup. Ct. Rep. 169, 174. In U. S. v. Ju Toy (1905) 198 U. S. 253, 260, 49 L. Ed. 1040, 25 Sup. Ct. Rep. 644, in holding an administrative finding to be conclusive, the court prefaced its opinion with: "We assume in what we have to say, as the questions assume, that no abuse of authority of any kind is alleged." (Italics mine.)

Compare: U.S.v.Tod (1923) 294 Fed. 628, 633, saying: "Where jurisdiction exists a finding of fact by the Executive Department is conclusive"; Live Oak etc. Assn. v. R. R. Com. (1923) 66 Cal. Dec. 408, 414, 219 Pac. 65, saying: "..... its findings and conclusions on questions of 'reasonableness and discrimination' are not subject to review by this court"; Marin W. Co. v. R. R. Com. (1916) 171 Cal. 706, 712-713, 154 Pac. 864, Ann. Cas. 1917C 114, saying that commission valuation for eminent domain "conclusively determines the facts."

17 Bergman v. Kearney (1917) 241 Fed. 884, 897.

18 Montesquieu, Esprit des lois, liv. xi, chap. 6.

19 Massachusetts Declaration of Rights, 1780. 
however, they have had to say that the principle was clearly broken, and have therefore declared the departure void as unconstitutional. So the attempt is now put forth to take the principle out of the Constitution, and turn backward to the unwholesome conditions which constitutional government displaced.

5. It will be supposed by many that only electricity distribution is being voted upon-("water and pawer" sound so much like "water power"). It will be supposed by others that perhaps water distribution will be included. In fact, as the Bill defines the purpose, it relates to anything cognate to the use of waters (sec. 3 , sub. a; see also sec. 1); comprehensive enough for supplying irrigation water to farmers and domestic water to cities in addition to electricity, and also for investing in hydraulic mines, and perhaps steamboat lines.

A little further on, beside "all powers needful for the accomplishment of the purposes of this article," the Bill provides also "such additional powers" (therefore not needful for that purpose) "as may be granted by the legislature." (sec. 3, sub. L). An effort, this apparently is, to remove in advance the state constitutional barriers from entering into any field-to clear the way for taking over oil, or railroads or the press-every kind of industry. The intention of the Bill evidently is to remove any state constitutional impediments from making its system universal.

A "Big Five" on the European model, of great power over the destinies of the State, would arrive, released from state constitutional precautions, and irresponsible to the people. To this "Cheka," as the Russians would call it, the Bill reads that "the faith and credit of the State of California is hereby pledged" (sec. 5), and all the rest of the State government are made its servants. "All public officers," section 15 enacts, "shall render every assistance in their power." It purports to put supreme power over the daily life of the people into the hands of five men, as though the people of California no longer cared for a share in their own affairs, and are to be as easily disposed of as the masses in Europe.

6. How far this would have to go before the Constitution of the Nation would interfere for the further reason of its assurance of a Republican form of government is a question that is not likely to be pressed to a conclusion. The Bill, having been defeated before, probably will secure still less support. Or if it carries there can be conceded a substantial chance that in practice the Board would operate a 
good deal short both of the extreme power for harm that is conferred upon it and of the power for good. Much always gets said on paper both ways that never gets going in practice. But while we continue to believe in self-government we should not approve a Bill devitalizing the Constitution, on the uncertainty of the chance that the Bill will not get enforced as it reads.

An address by Secretary Hughes declares that "the practice of putting large discretionary powers at the disposal of officers needs a curb. The patriot in peace demands government upon established principles, and he should always be ready to contest officialism and bureaucracy." It should not be too much to ask that those who seek to be entrusted with a vast fund and great power should submit themselves to the common constitutional safeguards against merely replacing the old abuses through a new set of men.

Samnel C. Wiel.

San Francisco, California. 